\title{
Pulmonary Function Test Decreased
}

National Cancer Institute

\section{Source}

National Cancer Institute. Pulmonary Function Test Decreased. NCI Thesaurus. Code C121577.

A decrease in any of the parameters used to measure the mechanical function of the lungs and upper airway. 